\title{
ANALISIS TINDAK TUTUR PADA BACAAN BUKU TEMATIK KELAS 5 TEMA 9 SUBTEMA 4
}

\section{ANALYSIS OF SPEECH ACT ON READING OF THEME 9 SUBTHEME 4 GRADE 5 THEMATIC BOOK}

\author{
Novita Putri Amalia, Aninditya Sri Nugraheni \\ Universitas Islam Negeri Sunan Kalijaga Yogyakarta \\ Jl. LaksdaAdisucipto, Papringan, Caturtunggal,Depok,Sleman,Yogyakarta \\ Pos-el : amalianovitama@gmail.com, anin.suka@gmail.com
}

*) Naskah diterima: 17 Juni 2020; direvisi: 3 September 2020; disetujui: 20 Oktober 2020

\begin{abstract}
Abstrak
Tindak tutur merupakan suatu ujaran untuk menyatakan maksud dan tujuan pembicara agar diketahui oleh pendengarnya. Tindak tutur memiliki bentuk yang bervariasi untuk menyatakan suatu tujuan. Setiap individu memiliki berbagai macam tindak tutur yang memiliki maksud dan tujuan tersendiri. Makna dari tindak tutur dapat dipahami berdasarkan penggunaan bahasa, dan juga aspek-aspek komunikasi.Penelitian ini menggunakan metode deskriptif kualitatifyang menghasilkan data deskriptif berupa tuturan yang tertulis dari bacaan buku tematik. Teknik pengumpulan data yang digunakan dalam penelitian ini adalah metode baca dan metode catat. Penelitian ini bertujuan untuk mengetahui tindak tutur apa saja yang terdapat pada bacaan di buku tematik dan apa maksud tuturan dalam dialog yang terdapat di buku tematik kelas 5 tema 9 subtema 4 . Terdapat tiga macam tindak tutur dalam buku tematik kelas 5 tema 9 subtema 4 yaitu tindak tutur lokusi, ilokusi, dan perlokusi.
\end{abstract}

Kata kunci: tindak tutur, wacana, buku tematik

\begin{abstract}
Speech act is a speech to state the intention and purpose of the speaker so that the listener knows it. Speech acts have various forms to express a purpose. Each individual has various kinds of speech acts that have their own goals and objectives. The meaning of speech acts can be understood based on the use of language, as well as aspects of communication. This study uses a qualitative descriptive method which produces descriptive data in the form of written speech from reading thematic books. The data collection techniques used in this study were the reading method and the note-taking method. This study aims to determine what speech acts are contained in the reading in the thematic books of class 5 theme 9 sub-themes 4 . There are three kinds of speech acts in thematic books of class 5 theme 9 subtheme 4, namely speech acts of locus, illocution, and perlocution.
\end{abstract}

Keywords: speech acts, discourse, thematic books

\section{PENDAHULUAN}

Bahasa merupakan kunci dalam komunikasi karena bahasa merupakan alat komunikasi di rangkaian manusia. Menurut Purba (2011: 1) komunikasi dapat diartikan sebagai suatu kegiatan pertukaran informasi antara pemberi informasi dan penerima informasi melalui suatu sistem simbol, lambang atau tanda, maupuan tingkah laku. Setiap ujaran yang diungkapkan me- 
miliki arti yang sesuai dengan kesepakatan dalam suatu lingkungan masyarakat. Komunikasi selalu menghasilkan informasi yang bisa berupa gagasan, maksud, perasaan, dan emosi yang dihasilkan secara langsung.

Bahasa sebagai alat komunikasi sangat berperan dalam kemajuan pola pikir manusia. Dalam kajian ilmu bahasa terdapat salah satu ilmu yang sangat akrab dalam kehidupan manusia yaitu pragmatik.

Oleh karena itu, dalam proses komunikasi terjadi peristiwa tutur atau biasa disebut sebagai tindak tutur (Heru, 2014:3). Tuturan manusia dapat diekspresikan melalui media masa baik lisan maupun tulis. Laila (dalam Tarigan, 1990:36) menyatakan berkaitan dengan tindak tutur, setiap ujaran atau ucapan tertentu mengandung maksud atau tujuan tertentu pula. Tindak tutur sebagai wujud peristiwa komunikasi bukanlah peristiwa yang terjadi dengan sendirinya, melainkan mempunyai fungsi, maksud, dan tujuan tertentu serta dapat menimbulkan pengaruh atau akibat pada mitra tutur.

Peristiwa tutur atau tindak tutur sendiri memiliki beberapa pengelompokan, yaitu lokusi, ilokusi, dan perlokusi.

Menurut Siti (2019:1) peristiwa tutur terjadi apabila ada tiga aspek di dalamnya, yakni penutur, mitra tutur, dan konteks tuturan. Syarat terjadinya peristiwa tutur dikaji dalam cabang ilmu bahasa pragmatik. Pengertian pragmatik menurut Leech (dalam Tarigan, 2015:25) adalah studi tentang makna dalam hubungannya dengan situasi-situasi ujar (speech situations) yang meliputi unsur-unsur penyapa dan yang disapa, konteks, tujuan, tindak ilokusi, tuturan, waktu, dan tempat. Dengan demikian, dapat disimpulkan bahwa pragmatik merupakan cabang ilmu bahasa yang mengkaji segala aspek makna tuturan berdasarkan maksud penutur.
Dalam pembelajaran siswa sekolah dasar diperlukan media pembelajaran, salah satunya adalah buku ajar. Di kurikulum 2013 ini sekolah menggunakan bahan ajar berupa buku tematik karena pembelajaran di sekolah dasar dengan kurikulum 2013 dilakukan secara tematik integratif.

Tidak seperti buku mata pelajaran pada kurikulum terdahulu, buku tematik ini mencakup semua mata pelajaran yang digabung dalam satu tema yang relevan dengan materi sekolah dasar. Dalam buku tematik kelas 5 tema 9 subtema 4 terdapat kegiatan berbasis literasi yang terdiri atas berbagai macam bacaan. Bacaan-bacaan yang terdapat dalam buku tematik kelas 5 tema 9 subtema 9 berisi tentang cerita-cerita dalam kehidupan sehari-hari. Banyak tindak tutur yang digunakan dalam kehidupan sehari-hari. Penggunaan tindak tutur memiliki maksud dan tujuan tertentu. Rohmadi (2014:5) menjelaskan bahwa setiap tuturan dalam suatu percakapan memiliki maksud dan tujuan. Tindak tutur yang disampaikan oleh seorang penutur, selain untuk menyampaikan informasi, juga memiliki maksud yang terkandung di balik tuturannya.

Masalah penelitian ini dapat dirumuskan menjadi apa sajakah tindak tutur yang terdapat dalam bacaan buku tematik dan apa maksud dari tuturan yang ada di buku tematik kelas 5 tema 9 subtema 4? Adapun tujuan penelitian ini, untuk mengidentifikasi tindak tutur yang terdapat dalam bacaan buku tematik dan memahami maksud tuturan yang diucapkan dalam dialog bacaan buku tematik kelas 5 tema 9 subtema 4.

\section{LANDASAN TEORI}

Pragmatik merupakan cabang lingusitik yang mengkaji bagaimana mitra tutur dapat memaknai tuturan dari penutur sehingga maksud tuturan dapat dipahami dan 
berpengaruh terhadap tindakan mitra tutur. Salah satu kajian pragmatik adalah tindak tutur.

Tindak tutur merupakan suatu tuturan yang memiliki makna tertentu atau mengandung suatu tindakan berdasarkan pada hubungan tuturan dengan tindakan penutur kepada mitra tuturnya. Menurut Abdurrahman (2006:14) tindak tutur (speech act) merupakan fungsi bahasa (language function), yaitu tujuan digunakan bahasa, seperti untuk memuji, meminta maaf, memberi saran, dan mengundang. Tindak tutur ini melibatkan penutur, mitra tutur dan tuturan. Lestari (2010:3) mengemukakan bahwa tindak tutur sebagai wujud peristiwa komunikasi bukanlah peristiwa yang terjadi dengan sendirinya, melainkan memunyai fungsi, mengandung maksud, dan tujuan tertentu serta dapat menimbulkan pengaruh atau akibat pada mitra tutur.

\section{METODE PENELITIAN}

Penelitian ini menggunakan metode deskriptif kualitatif dengan pendekatan pragmatik yang menghasilkan data deskriptif berupa tuturan yang tertulis dari bacaan buku tematik. Data-data dalam penelitian ini diperoleh dari tuturan dalam bacaan di buku tematik kelas 5 tema 9 subtema 4.

Teknik pengumpulan data yang digunakan dalam penelitian ini adalah metode baca dan metode catat. Analisis data dilakukan dengan menafsirkan tuturan dalam bacaan secara pragmatis.

\section{HASIL DAN PEMBAHASAN}

Tindak tutur merupakan bagian dari kajian pragmatik. Kegiatan tindak tutur ini melibatkan penutur, mitra tutur, dan tuturan. Tindak tutur dibagi menjadi tiga jenis tindakan yang berkaitan dengan ujaran, yaitu lokusi, ilokusi, dan perlokusi.

\section{Tindak Tutur Lokusi}

Tindak tutur lokusi merupakan tindak tutur yang berfungsi untuk menyatakan sesuatu yang bersifat informatif. Makna tuturan yang disampaikan berupa sebuah fakta atau keadaan yang sebenarnya. Tindak tutur lokusi merupakan tuturan yang sesuai dengan makna leksikalnya.

Dalam tindak tutur lokusi, informasi yang disampaikan merupakan informasi yang sebenarnya. Menurut Sholeh (2016:8), di dalam tindak lokusi tidak mempermasalahkan maksud atau fungsi tuturan.

Menurut Wiranty (2016:4), tindak tutur ilokusi dituturkan oleh penuturnya sematamata untuk menginformasikan sesuatu tanpa ada tendensi untuk melakukan sesuatu, apalagi untuk mempengaruhi lawan tuturnya. Tindak tutur lokusi ini tidak mengandung makna tersembunyi dibalik tuturannya dan tidak menimbulkan suatu tindakan atau efek terhadap mitra tuturnya. Penutur tidak membutuhkan tindakan dari mitra tutur atas tuturan yang diucapkan oleh mitra tutur selain sebuah informasi.

Tuturan dalam Bacaan Buku Tematik Kelas 5 Tema 9 Subtema 4 berikut ini merupakan contoh-contoh tuturan lokusi.

\section{Bacaan 1}

"Anak-anak kita sepakat akan menyanyikan dua buah lagu."

"Kalian harus memperhatikan tinggi rendah nada, pembagian suara, dan kekompakkan dalam bernyanyi."

\section{Bacaan 2}

"Besok paman antar kamu berkeliling pasar apung dengan perahu."

"Pantas saja pasar ini termasuk jenis pasar terunik." 
"Sudah sejak dari lahir mereka tinggal di sini, Danu. Mereka sudah terbiasa hidup berdampingan dengan alam."

"Rumah-rumah di sini tidak mudah rusak walaupun bahan bangunannya terbuat dari kayu, Danu. Kayu yang digunakan untuk membangun rumah masyarakat di sini adalah kayu ulin. Kayu ulin terkenal kuat dan semakin kuat apabila terkena air."

"Masyarakat di sini memanfaatkan hasil hutan berupa kayu ulin untuk membangun rumah."

"Ini pengalaman pertama Danu makan di atas perahu."

\section{Bacaan 3}

"Mala menjual slime buatannya kepada teman-temannya. Lamakelamaan banyak orang memesan slime kepadanya. Saat ini dia sudah memiliki beberapa karyawan yang membantu proses pengemasan slime karena Mala harus sekolah, usaha slime di rumahnya dikoordinasi oleh ibunya."

"Kita bisa bersaing dengan peserta lain dalam keahlian membuat slime."

\section{Bacaan 4}

"Rumah kami di Perumahan Permai. Hari ini kami ingin bersepeda keliling perumahan dan kampung. Saat tiba di kampung ini, kami melihat banyak warga terjun di sungai."

"Mereka sedang membersihkan sampah rumah tangga yang dibuang di sungai oleh orang tak bertanggung jawab. Mumpung aliran airnya tidak terlalu deras, kami ingin membersihkan sampah-sampah itu."

"Di kampung ini ada yang berprofesi sebagai perajin gerabah, karya- wan pabrik, guru, peternak lele, tukang bangunan, dan buruh serabutan."

"Sebagai contoh, untuk menciptakan kerukunan adalah dengan kerja bakti. Kerukunan membuat hidup menjadi tenang dan damai."

"Kalian memang anak-anak pintar. Bapak bangga bisa berkenalan dengan kalian."

\section{Bacaan 5}

“Mereka membantu mendorong kapal baru milik salah satu nelayan. Mungkin nelayan itu yang akan berlayar dengan kapal barunya nanti malam."

"Ini adalah kapal tradisional, Delisa. Perahu ini masih menggunakan tenaga manusia. Kapal ini berbeda dengan yang kamu lihat tadi. Kalau kapal yang didorong para nelayan dari daratan ke lautan tadi adalah kapal motor yang memiliki mesin. Kapal tadi memiliki ukuran lebih besar daripada kapal ini."

"Perlu kamu ketahui Nak, bahwa kapal bermesin merupakan bukti adanya perkembangan alat transportasi. Khususnya alat transportasi laut yang digunakan nelayan saat mencari ikan di laut."

"Alat transportasi yang digunakan nenek moyang kita untuk menjelajah menyusuri sungai adalah rakit. Rakit adalah alat transportasi air yang paling sederhana. Sampai saat ini pengembangan teknologi kapal laut masih terus dilakukan. Ingat, negara kita adalah perairan atau maritim. Jadi, alat transportasi yang dapat mengarungi perairan sangat dibutuhkan"

"Ibu sedang membantu suami memperhalus ukiran ini." 
"Suami ibu memproduksi alas Alquran dari kayu yang diukir. Alas ini diukir sendiri oleh suami ibu. Kemudian, ibu diminta memperhalus kayu ini."

"Suami ibu bukan seniman. Suami ibu memiliki keterampilan mengukir sejak muda. Ia belajar otodidak karena membantu usaha ayahnya sejak muda."

Semua tuturan yang ada pada bacaan 1 , 2, 3, dan 4 tersebut hanya menyatakan informasi. Penutur tidak membutuhkan tindak lanjut dari mitra tutur atas pernyataannya tersebut selain sebuah informasi. Karena tindak tutur lokusi hanya menyatakan sesuatu sesuai dengan arti yang sebenarnya.

\section{Tindak Tutur Ilokusi}

Tindak ilokusi adalah tindak tutur yang dilakukan untuk menyatakan maksud dan fungsi tertentu. Menurut Rasa (2019:6), dalam tindak tutur ini, satu tuturan mengandung dua maksud, yaitu menginformasikan dan menyuruh untuk melakukan sesuatu. Tuturan ilokusi selain berfungsi untuk menyampaikan atau menginformasikan sesuatu dan juga dapat melakukan sesuatu.

Tuturan ilokusi bermaksud untuk mendapat tindakan balik dari mitra tutur. Tindak tutur ilokusi merupakan tindak tutur yang mengandung makna tersembunyi atau makna lain yang dikehendaki oleh penutur terhadap mitra tutur.

Bacaan 1

"SD Nusantara terpilih mewakili Kecamatan Banyuwarna untuk mengikuti Festival dan Lomba Seni Siswa Nasional di tingkat Kabupaten Siliwangi."
Dalam kalimat tersebut penutur menyampaikan tuturan yang dimaksudkan untuk mendapat tindakan balik dari mitra tutur untuk mewakili SD Nusantara mengikuti lomba tersebut.

"Jika kalian tertarik mengikuti audisi harap segera mendaftar di tempat Bu Rastini."

Dalam kalimat tersebut penutur menyampaikan tuturan yang dimaksudkan untuk mendapat tindakan balik dari mitra tutur yaitu siswa mendaftarkan diri bagi yang berminat mengikuti audisi.

\section{Bacaan 2}

"Ayo, kita dekati penjual itu."

Dalam kalimat tersebut penutur menyampaikan tuturan yang dimaksudkan untuk mengajak mitra tutur yaitu paman, untuk mendekati penjual di pasar apung.

“Ayo, kita berkeliling lagi, Paman."

Dalam kalimat tersebut penutur menyampaikan tuturan yang dimaksudkan untuk mengajak mitra tutur yaitu pamannya, untuk mengelilingi pasar apung.
"Sudahlah Danu, mari kita makan dahulu. Jangan lupa berdoa terlebih dahulu, ya?"

Dalam kalimat tersebut penutur menyampaikan tuturan yang dimaksudkan untuk menyuruh mitra tutur untuk makan dengan berdoa terlebih dahulu.

\section{Bacaan 3}

"Iya, teman-teman. Aku berkata benar. Bagaimana kalau kita semua ikut kompetisi tersebut."

Dalam kalimat tersebut penutur menyampaikan tuturan yang dimaksudkan 
untuk mengajak mitra tutur untuk mengikuti kompetensi slime.

"Kita harus memberi tahu orang tua masing-masing. Kita minta izin kepada mereka."

Dalam kalimat tersebut penutur menyampaikan tuturan kepada mitra tutur agar mereka memberi tahu dan meminta izin kepada orang tua masing-masing bahwa mereka ingin mengikuti kompetisi slime.

\section{Bacaan 4}

"Saya punya usul, Pak. Bagaimana jika sungai kecil ini sudah bebas sampah, warga di sini memasang iklan layanan masyarakat. Iklan tersebut berisi ajakan agar masyarakat cinta lingkungan. Iklan tersebut juga menginformasikan bahwa warga di sini mendukung program kali bersih."

Dalam kalimat tersebut penutur menyampaikan tuturan yang dimaksudkan untuk memberikan masukan kepada mitra tutur untuk memasang iklan berisi ajakan agar masyarakat cinta lingkungan agar warga semakin sadar lingkungan dan menjaga kelestarian lingkungan di sekitarnya.

"Saya dengar kampung ini ada perajin gerabah, Pak. Kami ingin mengenal lebih dekat kegiatan perajin gerabah di kampung ini."

Dalam kalimat tersebut penutur menyampaikan tuturan yang dimaksudkan untuk mengajak mitra tutur berkunjung ke kampung melihat perajin gerabah.

\section{Bacaan 5}

“Kakek, ayo kita dekati ibu itu?"

Dalam kalimat tersebut penutur menyampaikan tuturan yang dimaksudkan untuk mengajak mitra tutur berjalan mendekati ibu tersebut.

"Hari semakin gelap. Besok kamu kembali lagi di sini."

Dalam kalimat tersebut penutur menyampaikan tuturan yang dimaksudkan untuk mengajak mitra tutur kembali ke penginapan.

\section{Tindak Tutur Perlokusi}

Dalam mengatakan sesuatu, apabila sebuah tuturan menimbulkan efek atau hasil pada mitra tutur, tindak tutur ini disebut dengan tindak tutur perlokusi.

Tindak tutur perlokusi adalah tindak tutur yang menghendaki adanya efek atau hasil dari sebuah tuturan.

Aziz (2012:11) mengatakan bahwa efek yang ditimbulkan dari tuturan perlokusi mempunyai maksud, yaitu antara untuk menyindir, berharap atau menginginkan, dan mempengaruhi. Hal ini merujuk pada pemaparan Fitriah (dalam Wijana 1989:19) bahwa "sebuah tuturan yang diutarakan oleh seseorang seringkali mempunyai daya pengaruh (perlocutionary force) atau efek bagi yang mendengarkannya."

\section{Bacaan 1}

“Anak-anak, kalian telah berjuang dengan kemampuan yang kalian miliki. Kalian telah berjuang maksimal sesuai latihan yang telah kita lakukan. Menang atau kalah dalam perlombaan ini tidak usah kalian pikirkan. Kita serahkan semuanya kepada panitia."

Tuturan tersebut diucapkan oleh seorang guru sebagai bentuk ungkapan penyemangat kepada para siswanya yang telah mengikuti festival seni. 
Bacaan 2

\section{"Benar-benar mengasyikkan, Paman."}

Tuturan tersebut diucapkan oleh Danu kepada pamannya karena Danu sangat senang mengelilingi pasar apung menggunakan perahu.

\section{Bacaan 3}

"Begini, aku kemarin membaca pengumuman. Pusat perbelanjaan Binar akan menyelenggarakan kompetisi pembuatan slime.

Tuturan tersebut memberikan efek penasaran kepada mitra tutur dan bermaksud untuk mendorong mitra tutur untuk ikut membaca lalu mengikuti kompetensi slime.

\section{“Berita apa, Dhia?"}

Tuturan tersebut memberikan efek kepada mitra tutur yang membuat mitra tutur menceritakan pengumuman yang telah ia baca.

\section{Bacaan 4}

"Dina! Teman-teman kamu sudah datang, Nak."

Dalam tuturan tersebut menimbulkan efek kepada mitratutur untuk segera keluar rumah untuk menemui teman-temannya yang sudah datang ke rumahnya.

"Hari ini kami ingin bersepeda keliling perumahan dan kampung. Saat tiba di kampung ini, kami melihat banyak warga terjun di sungai."

Tuturan tersebut mengungkapkan rasa ingin tahu terhadap kegiatan yang dilakukan oleh warga yang terjun ke sungai.
"Nanti orangtua kalian khawatir jika

kalian terlalu lama disini."

Tuturan ini membuat anak-anak bergegas pulang.

\section{Bacaan 5}

“Kok, perahu ini lebih kecil ya, Kek? Ini masih digunakan untuk nelayan atau tidak, ya?"

Tuturan ini mengungkapkan rasa ingin tahu Delisa mengenai perahu yang memberikan efek kepada kakek untuk menceritakan tentang teknologi perahu.

\section{PENUTUP}

Bentuk tindak tutur yang terdapat dalam bacaan di buku tematik kelas 5 tema 9 subtema 4 ialah tindak tutur lokusi, ilokusi, dan perlokusi.

Berdasarkan hasil analisis, tindak tutur yang paling banyak dituturkan dalam bacaan di buku tematik kelas 5 tema 9 subtema 4 yaitu tindak tutur lokusi karena buku tematik ini berisi tuturan yang bersifat informatif berupa sebuah fakta atau keadaan yang sebenarnya.

\section{DAFTAR PUSTAKA}

Susanti, H. 2014. Analisis Bentuk Tindak Tutur Pada Novel Rembulan Tenggelam Di Wajahmu. Surakarta: Universitas Muhammadiyah Surakarta.

Sholeh, K. 2016. Analisis Tindak Tutur Dalam Cerpen Burung Luri Karya Aryanti Sebagai Upaya Pembentukan Karakter Bangsa. Jurnal Pendidikan Surya Edukasi. Purworejo: Universitas Muhammadiyah Purworejo.

Laila, S. A. N., \& Admojo, W. 2019. Tindak Tutur Ilokusi Pada Novel Yorick Karya Kirana Kejora Dan Implikasinya Terhadap Pembelajaran Bahasa Indonesia Di Madrasah 
Aliyah. Program Doktoral IAIN Surakarta, Surakarta.

Rasa, M. P. D. B., Andayani, A., \& Ulya, C. 2019. Analisis Tindak Tutur Ilokusi Dalam Dialog Naskah Drama Peace Karya Putu Wijaya Dan Relevansinya Dengan Materi Ajar Sastra Di Sekolah Menengah Atas. Jurnal Bahasa, Sastra, dan Pengajarannya. Surakarta: Universitas Sebelas Maret.

Abdurrahman, A. 2006. Pragmatik: Konsep Dasar Memahami Konteks Tuturan. Jurnal Ilmu Bahasa dan Sastra. Malang: Universitas Islam Negeri Maulana Malik Ibrahim.

Wiranty, W. 2016. Tindak Tutur dalam Wacana Novel Laskar Pelangi Karya Andrea Hirata (Sebuah Tinjauan Pragmatik). Jurnal Pendidikan Bahasa. Pontianak: IKIP PGRI Pontianak.

Rohmadi, M. 2014. Kajian pragmatik percakapan guru dan siswa dalam pembelajaran Bahasa Indonesia. Jurnal Paedagogia. Surakarta: Universitas Sebelas Maret.
Lestari, A. T. 2010. Tindak Tutur Ilokusi dalam Wacana Ah Tenane pada Surat Kabar Solopos Edisi Mei 2010. Program Doktoral Universitas Muhammadiyah Surakarta, Surakarta.

Purba, A. 2011. Tindak Tutur dan Peristiwa Tutur. Jurnal Pendidikan Bahasa dan Sastra. Jambi: Universitas Jambi.

Aziz, S. R. 2012. Tindak Tutur Lokusi dan Perlokusi dalam Novel Surat Kecil Untuk Tuhan Karya Agnes Davonar. Program Doktoral Universitas Muhammadiyah Surakarta, Surakarta.

Fitriah, F., \& Fitriani, S. S. 2017. Analisis Tindak Tutur dalam Novel Marwah di Ujung Bara Karya RH Fitriadi. Master Bahasa. Banda Aceh: Universitas Syiah Kuala.

Laila, S. A. N., \& Admojo, W. 2019. Tindak Tutur Ilokusi Pada Novel Yorick Karya Kirana Kejora dan Implikasinya Terhadap Pembelajaran Bahasa Indonesia di Madrasah Aliyah. Program Doktoral IAIN Surakarta, Surakarta. 